\title{
Optimal timing for stage II: Waiting for Godot
}

\author{
Scott M. Bradley, MD
}

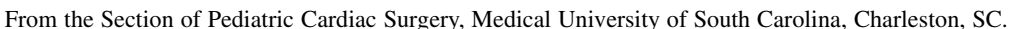

Disclosures: Author has nothing to disclose with regard to commercial support.

Received for publication Feb 28, 2017; accepted for publication March 2, 2017; available ahead of print March 30, 2017.

Address for reprints: Scott M. Bradley, MD, Pediatric Cardiac Surgery, Medical University of South Carolina,

CSB 424, 96 Jonathan Lucas St, Charleston, SC 29425 (E-mail: bradlesm@musc.edu).

J Thorac Cardiovasc Surg 2017;154:226-7

$0022-5223 / \$ 36.00$

Copyright (c) 2017 by The American Association for Thoracic Surgery

http://dx.doi.org/10.1016/j.jtcvs.2017.03.004

There is a relatively narrow window for second-stage surgery in patients after a Norwood procedure. Before 6 to 8 weeks of age, a superior cavopulmonary connection has an increased risk of failure due to hypoxia, superior vena cava congestion, and pleural effusions. ${ }^{1-4}$ Beyond 6 months of age, most neonatal shunts are outgrown and cyanosis becomes limiting. In practice, stage 2 palliation usually is carried out between 4 and 6 months of age. ${ }^{5}$ Nonetheless, appropriate timing within this window is a common issue and may vary from patient to patient. In this issue of the Journal, Barron and colleagues ${ }^{6}$ from Birmingham Children's Hospital examine the outcomes of stage II surgery with a particular focus on the effects of age and weight, and whether the surgery is planned (elective) or unplanned. The study includes 297 patients who underwent operation between 2002 and 2014. All patients had undergone a Norwood procedure with right ventricle-pulmonary artery shunt. Among the 297 patients, $222(75 \%)$ underwent planned stage II surgery, and $75(25 \%)$ underwent unplanned stage II surgery. Unplanned surgery generally occurred because of worsening desaturation or clinical deterioration.

The study's primary finding is that neither age nor absolute weight was associated with early or late mortality, although lower weight-for-age $Z$ score was associated with worse outcome. The strongest predictors of mortality were the need for atrioventricular (AV) valve repair, AV valve insufficiency, and poor ventricular function. Unplanned surgery occurred at a younger age (median $3.0 \mathrm{vs}$ 5.5 months), with higher operative mortality $(5.3 \%$ vs $1.3 \%$; not statistically significant) and worse survival at 5 and 10 years. However, unplanned surgery covaried with $\mathrm{AV}$ valve insufficiency and ventricular function, so that it was not significant in the multivariable model.

This article has several strengths: It comes from a group with recognized experience and expertise. It includes a large number of patients who had a uniform approach to a Norwood procedure, all with a right ventricle-pulmonary artery shunt, with $100 \%$ complete follow-up. The finding that $\mathrm{AV}$ valve function and ventricular function are the primary determinants of outcome at stage II surgery confirms

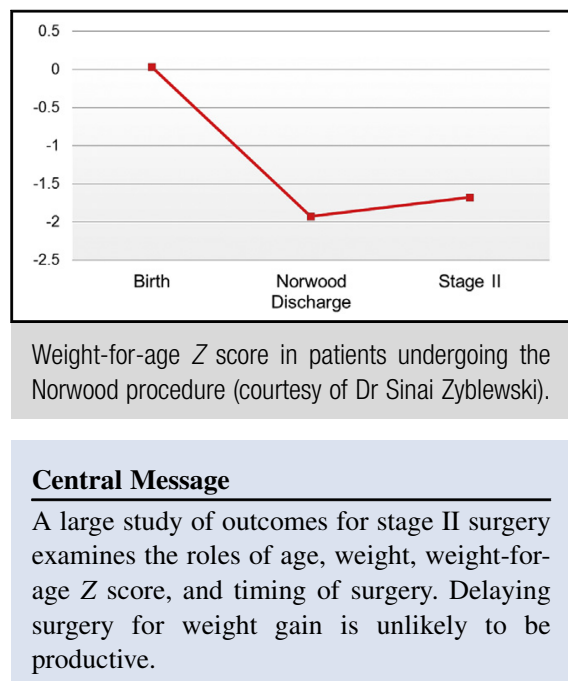

See Article page 228

previous publications on the topic. ${ }^{7,8}$ The effect of weightfor-age $Z$ score also is in line with a previous report.

Like most surgical studies, this study has the limitation of including only patients who actually underwent surgery, without accounting for those who did not make it to stage II. For patients who have undergone a Norwood procedure, this is an important limitation. In practice, a patient after a Norwood procedure is subject to the competing risks of stage II surgery or death or transplant before stage II. A decision on the appropriate timing of stage II surgery should account for the relative likelihood of each of these outcomes. It might then be possible to define an optimal age for stage II that both minimizes interstage death and maximizes post-stage II survival. This approach has recently been taken in the Congenital Heart Surgeons' Society study of optimal timing of Stage II palliation after the Norwood operation, the results of which were presented at the Society of Thoracic Surgeons annual meeting in January of this year. $^{10}$

What should we take away from this article? Are there patients in whom we should wait for growth before stage II surgery? Clearly, patients requiring unplanned surgery will have surgery when their clinical condition demands. For elective surgery, the authors' findings indicate that this is a forgiving operation: Neither age nor absolute weight has much effect on outcomes. A higher weightfor-age $Z$ score at the time of surgery is desirable; however, we know that this value does not increase appreciably over the interstage period. Interstage growth occurs, but not disproportionately to age. In my program's recent 


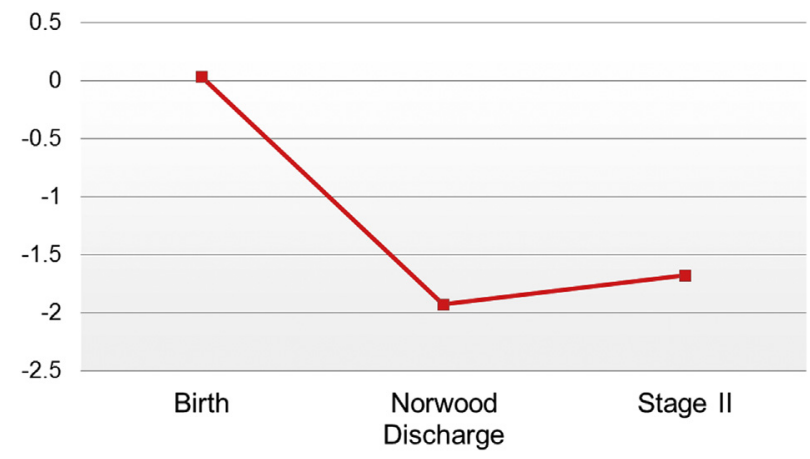

FIGURE 1. Weight-for-age $Z$ score in 27 patients undergoing the Norwood procedure January 2012 to December 2016. Figure courtesy of Dr Sinai Zyblewski.

experience, mean weight-for-age $Z$ score in patients who underwent the Norwood procedure was 0.03 at birth, -1.9 at the time of Norwood hospital discharge, and -1.7 at stage II, an interstage increase of only +0.2 (Figure 1). For comparison, in the current study a difference in weight-for-age $Z$ score of +1.4 was necessary to achieve significance in the multivariable model, and even then it remained less important than function of the AV valve and ventricle. Other studies have documented weight-for-age $Z$ score's resistance to positive change in patients with single ventricles. A National Pediatric Cardiology Quality Improvement Collaborative study of 465 patients found that weight for age $Z$ score was -1.5 at Norwood discharge and -1.3 at stage II, an average increase of $+0.2{ }^{11}$ In a more diverse group of patients with functional single ventricles, the Infant Single Ventricle Enalapril Trial found a mean decrease in weight-for-age $Z$ score of 0.37 from baseline to stage II. ${ }^{12}$ It seems that waiting for growth to decrease stage II operative risk will put us in the position of the 2 characters in Samuel Beckett's play Waiting for Godot $^{13}$ : awaiting an event that never arrives. A low weight-for-age $Z$ score may confer some operative risk, but in an individual patient this is unlikely to improve over time.

\section{References}

1. Reddy VM, Liddicoat JR, Hanley FL. Primary bidirectional superior cavopulmonary shunt in infants between 1 and 4 months of age. Ann Thorac Surg. 1995;59: 1120-6.

2. Slavik Z, Lamb RK, Webber SA, Devlin AM, Keeton BR, Monro JL, et al. Bidirectional superior cavopulmonary anastomosis: how young is too young? Heart. 1996;75:78-82.

3. Bradley SM, Mosca RS, Hennein HA, Crowley DC, Kulik TJ, Bove EL. Bidirectional superior cavopulmonary connection in young infants. Circulation. 1996 94:II5-11.

4. Reddy VM, McElhinney DB, Moore P, Haas GS, Hanley FL. Outcomes after bidirectional cavopulmonary shunt in infants less than 6 months old. J Am Coll Cardiol. 1997;29:1365-70.

5. Schwartz SM, Lu ML, Ohye RG, Hill KD, Atz AM, Naim MY, et al. Risk factors for prolonged length of stay after stage 2 procedure in the single-ventricle reconstruction trial. J Thorac Cardiovasc Surg. 2014;147:1791-8.

6. Barron DJ, Haq IUl, Crucean A, Stickley J, Botha P, Khan N, Jones TJ, Brawn WJ. The importance of age and weight on cavopulmonary shunt (stage II) outcomes after the Norwood procedure: planned versus unplanned surgery. J Thorac Cardiovasc Surg. 2017;154:228-38.

7. Scheurer MA, Hill EG, Vasuki N, Maurer S, Graham EM, Bandisode V, et al. Survival after bidirectional cavopulmonary anastomosis: analysis of preoperative risk factors. J Thorac Cardiovasc Surg. 2007;134:82-9.

8. Lee TM, Aiyagari R, Hirsch JC, Ohye RG, Bove EL, Devaney EJ. Risk factor analysis for second-stage palliation of single ventricle anatomy. Ann Thorac Surg. 2012;93:614-9.

9. Anderson JB, Beekman RH III, Border WL, Kalkwarf HJ, Khoury PR, Uzark K, et al. Lower weight-for-age $\mathrm{Z}$ score adversely affects hospital length of stay after the bidirectional Glenn procedure in 100 infants with a single ventricle. J Thorac Cardiovasc Surg. 2009;138:397-404.

10. Meza J, Hickey E, McCrindle BW, Blackstone E, Anderson BR, Overman DM et al. The optimal timing of stage-2 palliation after the Norwood operation: a multi-institutional analysis from the Congenital Heart Surgeons' Society. Presented at: the 53rd annual meeting of the Society of Thoracic Surgeons; January 23, 2017; Houston, TX.

11. Hill GD, Hehir DA, Bartz PJ, Rudd NA, Frommelt MA, Slicker J, et al. Effect of feeding modality on interstage growth after stage I palliation: a report from the national Pediatric Cardiology Quality Improvement Collaborative. J Thorac Cardiovasc Surg. 2014;148:1534-9.

12. Williams RV, Zak V, Ravishankar C, Altmann K, Anderson J, Atz AM, et al. Factors affecting growth in infants with single ventricle physiology: a report from the Pediatric Heart Network Infant Single Ventricle Trial. J Pediatr. 2011;159: 1017-22.

13. Beckett S. Waiting for Godot: a tragicomedy in two acts. New York, NY: Grove Press; 1954. 